\title{
A Descriptive Analysis of IPOs Post Listing Liquidity in Malaysia
}

\author{
Amal Mohammed Al-Masawa ${ }^{1,2}$, Rasidah Mohd-Rashid ${ }^{1} \&$ Hamdan Amer Al-Jaifi ${ }^{3}$ \\ ${ }^{1}$ School of Economics, Finance and Banking, College of Business, Universiti Utara Malaysia, Sintok, Malaysia \\ ${ }^{2}$ Department of Finance and Banking, Faculty of Administrative Sciences, Ibb University, Yemen \\ ${ }^{3}$ Taylor's Business School, Taylor's University, Subang Jaya, Malaysia \\ Correspondence: Amal Mohammed Al-Masawa, School of Economics, Finance and Banking, College of Business, \\ Universiti Utara Malaysia, Sintok, Malaysia.
}

Received: July 15, 2019

doi:10.5430/ijfr.v11n1p171
Accepted: October 16, 2019

Online Published: October 29, 2019

URL: https://doi.org/10.5430/ijfr.v11n1p171

\begin{abstract}
This study provides an overview of the issue of stock market liquidity among initial public offering (IPOs) by investigating the trend liquidity of IPOs for the period beginning 2002 through to 2017. Based on the Thompson Reuters DataStream database which provides data of Amihud's illiquidity measure (ILLIQ) for 304 IPOs Malaysian companies, detailed analysis shows that the corporate governance mechanisms plays an important role in increasing the transparency and disclosure of financial information, then reduces information asymmetries among market participants such as managers, large shareholders and investors, this leads increase stock market liquidity. The results of the study will be useful for firms through enables firms to know what factors are influence their stock market liquidity. Further, this study could have implications on regulating bodies such as Bursa Malaysia to help design regulations that could enhance stock market liquidity. Moreover, this study would provide implications for the investors and traders in terms of helping them on how to formulate their trading strategy.
\end{abstract}

Keywords: liquidity, IPOs, Bursa Malaysia, corporate governance mechanisms

\section{Introduction}

In the late twentieth century, there is increased interest in the field of research on corporate governance for two reasons, Firstly, the changes in the company governance (CG) brought about by new technologies, competition, globalisation and social and environmental concerns (Al-Rassas \& Kamardin, 2015). Secondly, the financial scandals in many companies in the world such as the failure of Enron in the U.S.A in December 2001 have had a specifically important role in increasing the influence of CG in the USA and other regions of the world, these financial scandals brought about by the conflict of interests between owners and managers (Hashim \& Devi, 2007). The conflict called for the need to establish governance regulations to monitor the actions of the managers in the companies (Ismail, Dunstan, \& Zijl, 2010).

The agency theory focuses on the division of ownership and management, between agents (managers) and principals (owners) which bring agency cost by way of controlling the agent's actions. To lower agency cost, more emphasis was made in creating a strict and practical CG codes as it is expected that good CG can improve the company's value. The effectiveness of management in controlling and utilizing company assets, including employees, and other assets will lead to greater CG because the cost of supervising and wastage of asset are avoided.

Effective CG assist in building a vibrant and effective stock market, investors have more trust in markets where firms have strict rules of CG (Prasanna \& Menon, 2012). Gilson (2001) indicated that stock investment needs good CG and good CG needs trustworthy information disclosures. In Malaysia, endeavours aimed at improving corporate governance system started in 1993 when the audit committee (AC) was made mandatory as part of the Kuala Lumpur Stock Exchange (KLSE) requirements for listing because of a major company fraud which happened in Bank Bumiputra, Perwaja Steel and Bank Islam (Haniffa \& Hudaib, 2006). The Asian 1997 financial crisis shed light on the weak corporate governance and governance standards, especially, weak board of directors (BOD) as a monitoring mechanism, which claimed to contribute to the crisis. Thus, an implementation of the corporate governance mechanisms has been conducted stage by stage to develop a good corporate governance reputation in Malaysia (Nam \& Nam, 2004). The most significant step taken towards improving the quality of CG is the execution of MCCG in March 2000, and the creation of Minority Shareholders Watchdog Group (MSWG) in 2001 (Johl, Johl, 
Subramaniam, \& Cooper, 2013). Both the Finance Committee on CG (FCCG) and the Malaysian Institute of Corporate governance were established in 1998 to conduct a reform and review of the country's corporate governance system. MCCG was established in March 2000. This code relates to four areas relating to accountability, BOD, remuneration of directors and shareholders. The code was later revised in 2007 (2007 Revised Code) in an attempt to improve the BOD effectiveness. The revised code (MCCG 2007) also states that all AC members should have financial expertise. In addition, all AC members should be nonexecutive directors, and the majority should be independent directors. Moreover, the board should lay down other corporate governance mechanisms to improve internal control monitoring in the form of an internal audit function (IAF) that is accountable to the AC (Hassan, Moyes, Mohd-Sanusi, \& Iskandar, 2010).

In 2012, the new MCCG (2012) was announced. It stated that the role of BOD should not be focusing on setting strategies only, but they should extend their role to be effective stewards and guardians of the firms. They should ensure that the firms comply with laws and ethical values. Besides, they are required to maintain an effective structure of corporate governance that would guarantee an appropriate risk management and internal controls. The new code concentrates on explaining the function of the board in providing leadership, improving the efficiency of the board through supporting its composition and independence. The code (MCCG, 2012) also covered the additional improvements, such as multiple directorships, and ensuring a timely level of internal control and high-quality disclosure. Overall, the 2007 and 2012 revisions made on the MCCG have the objective of strengthening the functions and responsibilities of the BOD and AC (Johl, Kaur, \& Cooper, 2015). In the context of developing nations like Malaysia, the implementation of good corporate governance practices reduces the susceptibility of the firm against financial crises and contributes to the development of economic sustainability (The World Bank Report, 2005).

Corporate governance has several effects on many aspects of the company, liquidity is one of them. As the stock market liquidity of well-governed firms would be improved. This argument is supported by the theoretical foundations of the agency theory (Jensen \& Meckling, 1976), the entrenchment theory (Shleifer \& Vishny, 1989) and the theory of stewardship (Davis, Schoorman, \& Donaldson, 1997). All of these theories support the association between the system of governance and information asymmetry. Glosten and Milgrom (1985) contended that the effect of CG mechanisms on liquidity of stock market can be explained by the adverse selection risk facing an investor when there is information asymmetry. Past literature have found that CG is linked with frequently released and more accurate voluntary information disclosure (Ajinkya, Bhojraj, \& Sengupta, 2005; Donnelly \& Mulcahy, 2008). Voluntary disclosure lowers asymmetric information and it also reduces adverse selection for investors (Coller \& Yohn, 1997; Diamond, 1985). Thus, a reduced information asymmetry and less agency conflict could enhance liquidity of stock (Brennan \& Subrahmanyam, 1995; Kyle, 1985).

Theoretically, corporate governance has an influence on liquidity of the stock market since effective CG ensures more supervision and control of managers, thereby guiding against inefficient and selfish management from hiding information. Hence, strong CG is expected to enhance transparency, which will then reduce asymmetric information (Chung et al., 2010). If asymmetric information is less, liquidity providers have less adverse selection problems, thus motivating them to buy stocks with better governance mechanisms (Glosten \& Milgrom, 1985). Consequently, companies with stronger governance will have more equity liquidity.

The main objective of this study is to investigate the liquidity trend among Malaysian initial public offerings for the period 2002 to 2017 in conjunction with the issuance of the corporate governance code and subsequent revisions of MCCG. Liquidity of stocks is important because it affects the expected return on stock and the cost of capital. Thus, the result it has an impact on the flow of capital and the upgrowth and development of the market. Therefore, it is an important to understand whether corporate governance can facilitate more liquidity in the market, especially in the emerging economy such as Malaysia. This study on the stock market liquidity provides in depth analysis into the situation of IPOs liquidity for the study period and sheds many interesting insights to companies, investors and policy makers. The rest of this paper is organized as follows: The following section will explain the review of literature in the liquidity of stock market. The methodology section then explains the data collection process. The results section describes the results of the analysis and discussion, while the conclusions section presents the study summary and its implications.

\section{Literature Review}

Liquidity is one of the significant attributes required for the well-functioning of stock markets. It is considered as a key factor in the development of the stock market due to the fact that a liquid market provides efficient allocation and helps economic growth (Bencivenga, Smith, \& Starr, 1996; Harris, 2003; Levine, 1991). Liquidity is defined as 
the ease of trading a security in the desired quantity, quickly and at low cost (Amihud \& Mendelson, 1986). Harris (2003) also defined liquidity as the ability to trade huge amount of stocks quickly, at minimal cost, and as at when needed. Recently, Ali et al., (2016) indicated that securities which could immediately be exchanged for cash or vice versa at very low cost are called "perfect liquid market". While, in an imperfect market, a liquid market, the transaction costs incurred on the conversion are minimized. It can be said that the lifeblood of the stock market is liquidity because of its prominent effects on all participants in the financial market such as traders, listed companies, regulatory bodies and stock markets (Kumar \& Misra, 2015). For traders, liquidity allows executing their trading strategies quickly and cheaply, both in terms of low price impact of transactions and low transaction costs (Harris, 2003). It is more efficient as they quickly absorb uninformative trades, leading to more informative prices (Kyle, 1985).

For regulators, stock market liquidity is required because liquid markets are often less volatile than illiquid ones (Harris, 2003). They are interested in the optimal design of the stock markets, which improves the quality of the market by increasing market liquidity and reducing transaction costs, thereby attracting more investors to trade and more companies to list their shares. In other words, maintaining a well-designed and highly liquid market maintains as many traders as possible in the market (Tayeh, 2010). Similarly, Liew, Lim and Goh (2016) indicated that enhancing the liquidity of stock markets is one of the major objectives of stock exchange regulators, aside from enabling efficient working of the stock markets, it is also major factor to be considered in stock investment decisions.

From the point of view of firms, liquidity allows rising of more capital at lower cost and increasing owners' wealth through portfolio diversification (Banti \& Jona, 2014). Therefore, companies can lower their capital cost through raising the stock liquidity, and this leads to increase firm value (Amihud \& Mendelson, 1986; Kumar \& Misra, 2015). In another word, stock liquidity influence company value by reducing capital cost and influencing corporate investments (Cheung, Chung, \& Fung, 2015). Stock market liquidity also has impact on the investor's expectation and firms' value. From the point of view of investors, according to Handa and Schwartz (1996), investors are after three things in the markets: 'liquidity, liquidity and liquidity'. This provides opportunity for investors to come in and go out of a market in an efficient manner thus enabling them to trade at a faster pace with low risk of sticking to one particular investment. It is also stated that investors want compensation for their risks and also for their transaction costs when exchanging their shares, therefore, stocks with lower liquidity have higher expected returns (Ali et al., 2016; Amihud \& Mendelson, 1986). Beside attention to risk and return, some investors and investment analysts pay more attention to liquidity as an important factor in their decision to buy or sell shares because the fact that higher liquidity lowers costs of transaction for future equities (Ibbotson \& Ritter, 1995). Generally, liquidity of stock market is an important attribute which influences investor decision making, and it plays an important part in the cross-sectional variation in stock returns (Foo \& Zain, 2010).

In respect of IPOs, high liquidity of the stock market is one of the issues that have to be addressed carefully. Corwin et al., (2004) noted that a critical element in the IPO's success is a liquid secondary market, in worst cases, inadequate liquidity of the secondary can lead to the failure or outright cancellation of an IPO, because liquidity decrease the transaction cost and reduces market volatility and it reduces required underpricing and it will difficult for the issuing firm to access the capital markets. Pham et al., (2003) also emphasized that the main objective of the IPO is achieving liquidity, because higher level of liquidity reduces transaction costs in future equity raisings, increases firm value, provides a better environment for managerial incentive schemes and improves market monitoring by encouraging information dissemination by speculators (Amihud \& Mendelson, 1986; Holmstrom \& Tirole, 1993; Ibbotson \& Ritter, 1995).

In IPOs, firms that are seeking for higher liquidity may underprice their stock since they are interested in attracting a larger number of small-scale investors to produce a wider ownership structure. But since they are at a disadvantage because of the little information they possess, smaller investors take part in an initial offering when they are adequately compensated for the unfavorable cost of selection they incur, that means when the IPO is highly underpriced (Gajewski \& Gresse, 2006). There are two opposing theories about underpricing and post-IPO liquidity. The first theory by Booth and Chua (1996) posited that underpricing serves as a way of ensuring a broad ownership structure and thus increase liquidity post-IPO. The hypothesis maintains that post-listing spreads and adverse selection are negatively linked to underpricing.

On the other hand, the second theory propounded by Ellul and Pagano (2006) assumed that post-IPO spreads and information asymmetry measures go up in line with underpricing since it is a consequence of cost of illiquidity expected to arise in the post-IPO. In other words, asymmetric information exists among participants in the IPO 
process, investors expect less liquidity. Thus, severe asymmetric information will lead to higher level underpricing, causing higher illiquidity.

Post-IPO liquidity provides an advantage for issuers since it decreases the company's capital cost because of the lesser liquidity risk premium demanded by investors. Eckbo and Norli (2005) used a sample (IPO) stocks in U.S.A for up to 5 years to investigate the risk-return features of a rolling portfolio investment plan. They measured post-IPO liquidity with turnover (monthly) calculated as volume of trading divided by the number of outstanding shares. They found that IPO stocks have more liquidity than non-IPO stocks of similar size and book-to-market value during the five years' period they investigated. Furthermore, a listing event enables the original shareholders to sell their shares in the company and recoup their initial holdings (Zingales, 1995). Prior studies claim that the value of liquidity may be different among different firms' owners. For example, Hahn et al., (2013) argued that very liquid shares permit the remaining stock to be exchanged at prices that gives higher returns. However, Ellul and Pagano (2006) demonstrated that investors are happy with lesser returns on very liquid offers thus allowing issuers to give out the new shares at the highest or optimal prices. Higher liquidity is important even if the liquidation of internal shareholdings is not the main aim of the IPO. Liquidity also creates public shares that IPO companies can utilize in further acquiring and increasing the worth of share-holdings of pre-IPO investors (Brau \& Fawcett, 2006).

\section{Methodology}

This study uses a descriptive approach to provide insights on the occurrences of liquidity among Malaysian IPOs companies. There are no prior studies in Malaysia that analyze the trend of IPOs liquidity (Note 1). Limited studies have focused on the stock liquidity of Malaysian listed companies (Al-Jaifi et al., 2017; Azevedo, Karim, Gregoriou, \& Rhodes, 2014; Foo \& Zain, 2010; Lim, Thian \& Hooy, 2017; Subramaniam, Samuel and Mahenthiran, 2016), two study focused on the liquidity of Malaysian IPOs by (Ramlee \& Ali, 2012; Sapian, Rahim, \& Yong, 2013). Ramlee and Ali (2012) who focused on effect of underpricing, government ownership on liquidity for long-term (more than one year) whereas Sapian et al., (2013) focused on influence of underpricing on the aftermarket liquidity for short-term (60 trading days). These two studies on liquidity using Malaysian data, focused on factors unrelated to corporate governance such as IPO underpricing or government ownership on liquidity of IPO long term. In this study, we attempt to extend on the study by Sapian et al., (2013) by analyzing liquidity of IPOs over a longer period.

A total of 535 new issues were reviewed from 2002 to 2017. The present study selects IPOs that are presented as public issue, private placement, offer-for-sale, or a crossbred of any of these forms similar to Abdul-Rahim and Yong (2008) and Mohd Rashid, Abdul-Rahim, and Yong, (2014). The current study excludes IPOs which include special types of offers such as special issues, restricted public issue, restricted offer-for-sale, restricted offer-for-sale to eligible employees, restricted offer-for-sale to Bumiputra (Malays and indigenous people) investors, special and restricted issues to Bumiputra investors and tender offers. Abdul-Rahim and Yong (2008) and Rashid et al (2014) show that these uncommon types of issues can be excluded to avoid less meaningful results. Furthermore, the current study also excludes the Real Estate Investment Trust (REITS), (close ended) and (SPAC) due to different form of presentation of the financial statements. Also, this study excludes IPOs involving a financial company because these companies have unique characteristics, different compliance and regulatory environment. Finally, the current study excludes the data for the first five trading days to avoid the impact of abnormal trading activities due to flipping activities or price support by underwriters that may have a significant impact on post-listing liquidity(Corwin $e t$ al., 2004; Miloud, 2014; Pham et al., 2003). To get the final sample, companies were excluded which lack of its prospectus and other data related to the variables used in this study. Table 1 below summarizes the IPO sample based on the year of listing. These selection criteria provide a final sample of 304 IPOs after deleted outliers. The data in this study were analyzed using STATA version 14. 
Table 1. Distribution of IPOs sample by year of listing 2002 to 2017

\begin{tabular}{|c|c|c|c|c|c|c|c|c|c|c|c|c|c|c|c|c|c|}
\hline & 2002 & 2003 & 2004 & 2005 & 2006 & 2007 & 2008 & 2009 & 2010 & 2011 & 2012 & 2013 & 2014 & 2015 & 2016 & 2017 & $\begin{array}{l}\text { TOTAL } \\
\text { IPOS }\end{array}$ \\
\hline $\begin{array}{l}\text { IPO } \\
\text { Population }\end{array}$ & 52 & 73 & 74 & 80 & 41 & 29 & 23 & 15 & 29 & 28 & 17 & 19 & 14 & 14 & 12 & 15 & 535 \\
\hline $\begin{array}{l}\text { Exclude } \\
\text { due to } \\
\text { missing } \\
\text { data } \\
\text { variables }\end{array}$ & 22 & 32 & 26 & 32 & 21 & 16 & 12 & 6 & 7 & 13 & 8 & 10 & 4 & 6 & 3 & 6 & 224 \\
\hline $\begin{array}{l}\text { Exclude } \\
\text { missing } \\
\text { data } \\
\text { (IIIIQ) }\end{array}$ & & & 2 & 2 & & & & & & & & 1 & 1 & & & & 6 \\
\hline $\begin{array}{l}\text { Drop case } \\
\text { due to } \\
\text { Outliers }\end{array}$ & & 1 & & & & & & & & & & & & & & & \\
\hline $\begin{array}{l}\text { Final } \\
\text { Sample }\end{array}$ & 30 & 40 & 46 & 46 & 20 & 13 & 11 & 9 & 22 & 15 & 9 & 8 & 9 & 8 & 9 & 9 & 304 \\
\hline
\end{tabular}

\section{Results and Discussions}

The descriptive statistics of the ILLIQ by focusing on the overall mean and then, the mean on yearly basis. The Table 2 presents the mean on yearly basis for the whole sample's over the years 2002 to 2017 for the period 60 days, 120 and 180 days respectively. Based on Amihud's illiquidity measure (ILLIQ) the higher value of this measure indicates less liquidity (Note 2).

Table 2. Descriptive statistics of the illiquidity for the full sample of 304 IPOs over the period 60,120 and 180 days respectively

\begin{tabular}{llll}
\hline Year & ILLIQ60 & ILLIQ120 & ILLIQ180 \\
\hline 2002 & 0.000619 & 0.001669 & 0.002799 \\
\hline 2003 & 0.000158 & 0.000278 & 0.000885 \\
\hline 2004 & 0.000262 & 0.002038 & 0.002991 \\
\hline 2005 & 0.002596 & 0.006475 & 0.006491 \\
\hline 2006 & 0.000405 & 0.00053 & 0.002443 \\
\hline 2007 & 0.000263 & 0.000788 & 0.007388 \\
\hline 2008 & 0.016156 & 0.023937 & 0.017044 \\
\hline 2009 & 0.00012 & 0.000275 & 0.00555 \\
\hline 2010 & 0.000849 & 0.002791 & 0.002299 \\
\hline 2011 & 0.000284 & 0.001718 & 0.006402 \\
\hline 2012 & $7.68 \mathrm{E}-05$ & 0.000102 & 0.000177 \\
\hline 2013 & 0.000091 & 0.001598 & 0.005489 \\
\hline 2014 & $3.48 \mathrm{E}-05$ & 0.000179 & 0.000164 \\
\hline 2015 & 0.000499 & 0.000311 & 0.00023 \\
\hline 2016 & $2.81 \mathrm{E}-05$ & 0.000215 & 0.00017 \\
\hline 2017 & $3.21 \mathrm{E}-05$ & 0.000112 & 0.000291 \\
\hline Total & 0.001237 & 0.002782 & 0.00374 \\
\hline
\end{tabular}

As show in Figure 1, the liquidity is in the same level for all IPOs companies. It means those companies that experience low liquidity level for the first 60 days would be in low level for the 120 and 180 days. it means the 
information's from the prospectus are matter. In more detail, in 2002, the average (ILLQ) was 0.0006192, 0.001669 and 0.002799 for ILLIQ 60, ILLIQ 120 and ILLIQ 180 respectively, and it is continued to rise in subsequent years until 2007, this mean the level of liquidity is low during these years. Then, the highest IILIQ ratio is reported in year in 2008 where the mean value was $(0.0161558,0.023937 \& 0.017044)$ for the period 60 days, 120 and 180 days respectively, this refer to the declined the trading volume, thus reducing the level of liquidity. Then, the average declined (ILLQ) in the following years and lowest IILIQ was reported in years 2012, 2014, 2016 and 2017 where the mean values are $7.68 \mathrm{E}-05 \%, 3.48 \mathrm{E}-05 \%, 2.81 \mathrm{E}-05 \%$ and $3.21 \mathrm{E}-05 \%$ respectively for 60 days. This decline implies that the level of liquidity is improving after financial crisis. Similarly, liquidity improved in the years following the global financial crisis for the period 120 days. While the liquidity did not improve significantly during the 180 days period as shown in Figure 1.

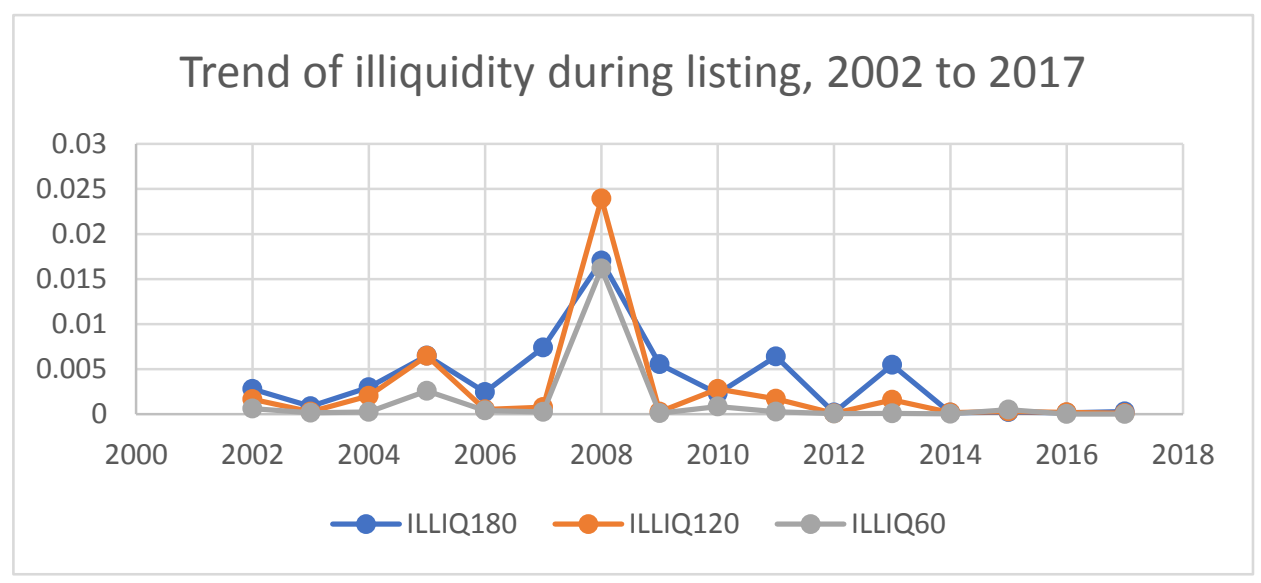

Figure 1. Trend of illiquidity during listing, 2002 to 2017

Overall, it can be said that the analysis of average yearly illiquidity (ILLQ) reveals different pattern with mean illiquidity before and after financial crisis year 2008. In other words, the liquidity is low during the financial crisis because the trading volume is not high due to the investors are not sell or buy stocks easily and they are afraid of uncertainty with IPO firms. In addition to the impact of the global financial crisis in 2008, there is another reason for the low level of liquidity is the extreme values of some companies such as SUNZEN BIOTECH BERHAD, which has the highest value by $(0.15223,0.120225 \& 0.068275)$ percent for three periods 60,120 and 180 days respectively.

One of the reasons that could be linked to the improvement in the liquidity in the Malaysian context, is the Malaysian Code on Corporate Governance (MCCG) which was issued in 2000, where it revised in 2007, 2012 and 2017, to ensure greater quality practices of corporate governance and to improve transparency as well as investors' confidence. When corporate governance mechanisms are strong lead to enhance the transparency, both operationally and financially, by reducing the information asymmetry between managers and large shareholders as inside and outside owners; and liquidity providers as outside investor. Firms with better corporate governance are more likely to disclose relevant information lead to improve the informational environment, effective disclosure regulation and effective protection of shareholder, lead to higher market liquidity. Briefly, strong corporate governance mechanisms represent a good signal of market efficiency and the people are getting good more confident on financial market and they will go to the market and increase liquidity of stocks by selling and buying the stocks.

Take a close look at the descriptive statistics of liquidity in the study full sample and sub-samples are listed in Panels A, B and C of Table 3 during the revisions of MCCG in (2007, 2012 \& 2017). Among the 190 IPOs, the means of liquidity for the total sample are $0.00123,0.00278$ and 0.00374 percent, respectively for the three period 60,120 and 180 days. With regard to the IPO companies during 2002-2006 Which includes of the Code of Corporate Governance issue (MCCG) in 2000, the average values are 0.00090, 0.00253 and 0.00331 percent for the ILLIQ60, ILLIQ120 and ILLIQ 180 days respectively. whilst, the average of IPOs during the first revised of MCCG in 2007 was $0.00293,0.00518$ and 0.00685 percent for the 60,120 and 180 days respectively, indicating that the liquidity level of IPO companies improved after implementation of MCCG (2007). Likewise, from 2012 to 2017 the average 
for (ILLIQ60, ILLIQ120, ILLIQ180) was 0.00012, 0.00039 and 0.00101 percent respectively. This result shows that the liquidity of IPOs tends to be better at every stage of the implementation of MCCG over the year 2000 until 2017.

In view of previous studies that examined the Malaysian IPOs liquidity, Ramlee and Ali (2012) and Sapian et al. (2013) showed that the average trading volume was 3.25 percent of the total IPO issued and the average of turnover which is 3.7 percent of the total shares outstanding, for 191 IPOs during 60 days after the first week the IPOs are listed from 2003 to 2008 in Sapian et al. (2013). Ramlee and Ali, (2012) used another measurement of liquidity for 283 IPOs stocks listed on Bursa Malaysia from 1998 to 2008. They have been used monthly turnover and turnover volatility ratio as a proxy for liquidity in examined the relation between long-term return (12, 24 \& 36 -month) and liquidity. The average of turnover was 11.54, 9.06 and 7.85 percent for the period of 12, 12,24 and 36 months respectively. The difference with these recent studies may be attributed to the sample as this study only concentrates on IPOs that are underpriced or difference in length of period.

Table 3. Descriptive statistics based on the sub-samples

\begin{tabular}{|c|c|c|c|c|c|}
\hline variable & Mean & Median & SD & Minimum & Maximum \\
\hline \multicolumn{6}{|c|}{ Panel A: All sample IPO companies $(n=304)$} \\
\hline ILLIQ60 & 0.001237 & $9.53 \mathrm{E}-05$ & 0.009502 & $9.37 \mathrm{E}-08$ & 0.152238 \\
\hline ILLIQ120 & 0.002782 & 0.000202 & 0.012684 & $9.10 \mathrm{E}-08$ & 0.120225 \\
\hline ILLIQ180 & 0.00374 & 0.000366 & 0.011855 & $9.10 \mathrm{E}-08$ & 0.084821 \\
\hline \multicolumn{6}{|c|}{ Panel B: IPO companies during 2002-2006 $(\mathrm{n}=182)$} \\
\hline ILLIQ60 & 0.000904 & 0.000157 & 0.00471 & $1.33 \mathrm{E}-06$ & 0.059495 \\
\hline ILLIQ120 & 0.002538 & 0.000308 & 0.011041 & $2.11 \mathrm{E}-06$ & 0.106564 \\
\hline ILLIQ180 & 0.003318 & 0.000578 & 0.009774 & $2.07 \mathrm{E}-06$ & 0.082924 \\
\hline \multicolumn{6}{|c|}{ Panel B: IPO companies during 2007-2011 $(\mathrm{n}=70)$} \\
\hline ILLIQ60 & 0.002931 & $9.67 \mathrm{E}-05$ & 0.018274 & $9.37 \mathrm{E}-08$ & 0.152238 \\
\hline ILLIQ120 & 0.005189 & 0.000277 & 0.019343 & $9.10 \mathrm{E}-08$ & 0.120225 \\
\hline ILLIQ180 & 0.006858 & 0.000461 & 0.017994 & $9.10 \mathrm{E}-08$ & 0.084821 \\
\hline \multicolumn{6}{|c|}{ Panel B: IPO companies during 2012-2017 $(\mathrm{n}=52)$} \\
\hline ILLIQ60 & 0.00012 & 1.79E-05 & 0.000544 & $2.32 \mathrm{E}-07$ & 0.003916 \\
\hline ILLIQ120 & 0.000399 & $3.14 \mathrm{E}-05$ & 0.001761 & $3.72 \mathrm{E}-07$ & 0.012526 \\
\hline ILLIQ180 & 0.001019 & $4.34 \mathrm{E}-05$ & 0.006027 & $4.11 \mathrm{E}-07$ & 0.043568 \\
\hline
\end{tabular}

\section{Conclusion}

This study capitalizes on data available on the Thompson Reuters DataStream database, where 304 of IPOs were investigated to determine whether there has been an improvement in the liquidity of shares during each stage of the amendments to the Code of MCCG from 2002 to 2017. This study found that there was a direct negative impact of the 2008-2009 global financial crisis on the Malaysian business environment because Investors' uncertainty about IPO companies as well as increase uncertainty about the efficiency of the market. Therefore, Investors do not buy or sell shares easily, and the liquidity level tended to fall. Furthermore, the results of this study indicate that improvement liquidity of IPOs at every stage of the implementation of MCCG over the year 2000 until 2017. This means the (MCCG) plays an important role in increasing the transparency and disclosure of financial information. When corporate governance is strong, it promotes operational and financial transparency and increases the quality of financial disclosure, then reduces information asymmetries among market participants such as managers and large shareholders, as inside and outside owners; and liquidity providers as outside investor. In other words, strong corporate governance mechanisms represent a good signal of market efficiency and the people are getting good more confident on financial market and they will go to the market and increase liquidity of stocks by selling and buying the stocks, consequently, lead to higher market liquidity. 


\section{References}

Abdul-Rahim, R., \& Yong, O. (2008). Initial returns of Shariah-compliant IPOs in Malaysia. Capital Markets Review, 16(2), 399-52.

Ajinkya, B., Bhojraj, S., \& Sengupta, P. (2005). The association between outside directors, institutional investors and the properties of management earnings forecasts. Journal of Accounting Research, 43(3), 343-376. https://doi.org/10.1111/j.1475-679x.2005.00174.x

Ali, S., Liu, B., \& Su, J. J. (2016). What determines stock liquidity in Australia ?. Applied Economics, 48(35), 3329-3344. https://doi.org/10.1080/00036846.2015.1137552

Al-Jaifi, H. A., Al-rassas, A. H., \& AL-Qadasi, A. A. (2017). Corporate governance strength and stock market liquidity in Malaysia. International Journal of Managerial Finance, 3-21. https://doi.org/10.1108/IJMF-10-2016-0195

Al-Rassas, A. H., \& Kamardin, H. (2015). Directors' independence, internal audit function, ownership concentration and earnings quality in Malaysia. Asian Social Science, 11(15), $244-256$. https://doi.org/10.5539/ass.v11n15p244

Amihud, Y., \& Mendelson, H. (1986). Asset pricing and the bid-ask spread. Journal of Financial Economics, 17, 223-249. https://doi.org/10.1016/0304-405X(86)90065-6

Azevedo, A., Karim, M., Gregoriou, A., \& Rhodes, M. (2014). Stock price and volume effects associated with changes in the composition of the FTSE Bursa Malaysian KLCI. Journal of International Financial Markets, Institutions and Money, 28(1), 20-35. https://doi.org/10.1016/j.intfin.2013.10.001

Banti, C., \& Jona, J. (2014). Illiquidity dynamics of newly listed stocks : evidence from foreign IPOs in the US.

Bencivenga, V. R., Smith, B. D., \& Starr, R. M. (1996). Liquidity of secondary capital markets: Allocative efficiency and the maturity composition of the capital stock. Economic Theory, 7(1), 19-50. https://doi.org/10.1007/BF01212180

Booth, J. R., \& Chua, L. (1996). Ownership dispersion, costly information, and IPO underpricing. Journal of Financial Economics, 41(2), 291-310. https://doi.org/10.1016/0304-405X(95)00862-9

Brau, J. C., \& Fawcett, S. E. (2006). Initial public offerings : An analysis of theory and practice. The Journal of Finance, LXI(1), 399-436. https://doi.org/10.1111/j.1540-6261.2006.00840.x

Brennan, M. J., \& Subrahmanyam, A. (1995). Investment analysis and price formation in securities markets. Journal of Financial Economics, 38(3), 361-381. https://doi.org/10.1016/0304-405X(94)00811-E

Cheung, W. M., Chung, R., \& Fung, S. (2015). The effects of stock liquidity on firm value and corporate governance: Endogeneity and the REIT experiment. Journal of Corporate Finance, 35, 211-231. https://doi.org/10.1016/j.jcorpfin.2015.09.001

Chung, K. H., Elder, J., \& Kim, J. (2010). Corporate governance and liquidity. Journal of Financial and Quantitative Analysis, 45(02), 265-291. https://doi.org/10.1017/S0022109010000104

Coller, M., \& Yohn, T. L. (1997). Management forecasts and information asymmetry: An examination of bid-ask spreads. Journal of Accounting Research, 35(2), 181-191. https://doi.org/10.2307/2491359

Corwin, S. A., Harris, J. H., \& Lipson, M. L. (2004). The development of secondary market liquidity for NYSE-Listed IPOs. Journal of Finance, 59(5), 2339-2373. https://doi.org/10.1111/j.1540-6261.2004.00701.x

Davis, J. H., Schoorman, D., \& Donaldson, L. (1997). Toward a stewardship theory of management. Academy of Management Review, 22(1), 20-47. https://doi.org/10.5465/amr.1997.9707180258

Diamond, D. W. (1985). Optimal release of information by firms. The Journal of Finance, 40(4), 1071-1094. https://doi.org/10.1111/j.1540-6261.1985.tb02364.x

Donnelly, R., \& Mulcahy, M. (2008). Board structure, ownership, and voluntary disclosure in Ireland. Corporate Governance: An International Review, 16(5), 416-429. https://doi.org/10.1111/j.1467-8683.2008.00692.x

Eckbo, B. E., \& Norli, O. (2005). Liquidity risk, leverage and long-run IPO returns. Journal of Corporate Finance, 11(1-2), 1-35. https://doi.org/10.1016/j.jcorpfin.2004.02.002

Ellul, A., \& Pagano, M. (2006). IPO underpricing and after-market liquidity. Review of Financial Studies, 19(2), 381-421. https://doi.org/10.1093/rfs/hhj018 
Foo, Y.-B., \& Zain, M. M. (2010). Board independence, board diligence and liquidity in Malaysia : A research note. Journal of Contemporary Accounting \& Economics Journal, 6, 92-100. https://doi.org/10.1016/j.jcae.2010.10.001

Gajewski, J.-F., \& Gresse, C. (2006). A survey of the european IPO market. ECMI Research Paper, 2.

Gilson, R. J. (2001). Globalizing corporate governance: Convergence of form or function. The American Journal of Comparative Law, 49(2), 329-357. https://doi.org/10.2307/840814

Glosten, L. R., \& Milgrom, P. R. (1985). Bid, ask and transaction prices in a specialist market with heterogeneously informed traders. Journal of Financial Economics, 14(1), 71-100. https://doi.org/10.1016/0304-405X(85)90044-3

Hahn, T. W., Ligon, J. A., \& Rhodes, H. (2013). Liquidity and initial public offering underpricing. Journal of Banking and Finance, 37(12), 4973-4988. https://doi.org/10.1016/j.jbankfin.2013.09.004

Handa, P., \& Schwartz, R. A. (1996). How best to supply liquidity to a securities market. The Journal of Portfolio Management, 22(2), 44-51. https://doi.org/10.3905/jpm.1996.44

Haniffa, R., \& Hudaib, M. (2006). Corporate governance structure and performance of malaysian listed companies. $\begin{array}{lllll}\text { Journal of Business } & \text { Finance } \& \quad \text { Accounting, } & 33(7-8), & \text { 1034-1062. }\end{array}$ https://doi.org/10.1111/j.1468-5957.2006.00594.x

Harris, L. (2003). Trading and exchanges: Market microstructure for practitioners. Oxford University Press, USA.

Hashim, H. A., \& Devi, S. (2007). Corporate governance, ownership structure and earnings quality: Malaysian evidence. Research in Accounting and Emerging Economies, 8, 97-123. https://doi.org/10.1016/S1479-3563(08)08004-3

Hassan, M.-H., Moyes, G. D., Mohd-Sanusi, Z., \& Iskandar, T. M. (2010). The enforcement role of the companies' commission of Malaysia. The International Business \& Economics Research Journal. https://doi.org/10.19030/iber.v9i2.530

Holmstrom, B., \& Tirole, J. (1993). Market liquidity and performance monitoring. The Journal of Political Economy, 101(4), 678-709. https://doi.org/10.1086/261893

Ibbotson, R. G., \& Ritter, J. R. (1995). Initial public offerings. Handbooks in Operations Research and Management Science, 9, 993-1016. https://doi.org/10.1016/S0927-0507(05)80074-X

Ismail, W. A. W., Dunstan, K., \& Zijl, T. van. (2010). Earnings quality and corporate governance following the implementation of Malaysian code of corporate governance, pp. 1-40.

Jensen, M. C., \& Meckling, W. H. (1976). Theory of the firm : Managerial behavior, agency costs and ownership structure. Journal of Financial Economics, 3(4), 305-360. https://doi.org/10.1016/0304-405X(76)90026-X

Johl, S. K., Johl, S. K., Subramaniam, N., \& Cooper, B. (2013). Internal audit function, board quality and financial reporting quality: Evidence from Malaysia. Managerial Auditing Journal, 28(9), 780-814. https://doi.org/10.1108/MAJ-06-2013-0886

Johl, S. K., Kaur, S., \& Cooper, B. J. (2015). Board Characteristics and Firm Performance: Evidence from Malaysian Public Listed Firms. Journal of Economics, Business and Management, 3(2), 239-243. https://doi.org/10.7763/JOEBM.2015.V3.187

Kumar, G., \& Misra, A. K. (2015). Closer view at the stock market liquidity : A Literature Review. Asian Journal of Finance and Accounting, 7(2), 35-57. https://doi.org/10.5296/ajfa.v7i2.8136

Kyle, A. S. (1985). Continuous auctions and insider trading. The Econometric Society, 53(6), 1315-1335. https://doi.org/10.2307/1913210

Levine, R. (1991). Stock markets , growth , and tax policy. The Journal of Finance, 46(4), 1445-1465. https://doi.org/10.1111/j.1540-6261.1991.tb04625.x

Liew, P.-X., Lim, K.-P., \& Goh, K.-L. (2016). Aggregate liquidity for Malaysian stock market: New indicators and time series properties. International Journal of Economics and Management, 10(2), 297-319.

Lim, K.-P., Thian, T.-C., \& Hooy, C.-W. (2017). Investor heterogeneity, trading account types and competing liquidity channels for Malaysian stocks. Research in International Business and Finance. https://doi.org/10.1016/j.ribaf.2017.04.019 
Miloud, T. (2014). Offer price, target ownership structure and post-listing liquidity of newly listed firms. Managerial Finance, 40(9), 928-950. https://doi.org/10.1108/MF-06-2013-0127

Mohd Rashid, R., Abdul-Rahim, R., \& Yong, O. (2014). The influence of lock-up provisions on IPO initial returns: Evidence from an emerging market. Economic Systems, 38(4), 487-501. https://doi.org/10.1016/j.ecosys.2014.03.003

Nam, S., \& Nam, I. C. (2004). Corporate governance in Asia: Recent evidence from Indonesia, Republic of Korea, Malaysia, and Thailand. Asian Development Bank Institute.

Pham, P. K., Kalev, P. S., \& Steen, A. B. (2003). Underpricing, stock allocation, ownership structure and post-listing liquidity of newly listed firms. Journal of Banking and Finance, 27(5), 919-947. https://doi.org/10.1016/S0378-4266(02)00241-8

Prasanna, P. K., \& Menon, A. S. (2012). Corporate governance and stock market liquidity in India. International Joural Behavioural Accounting and Finance, 3, 24-45. https://doi.org/10.1504/IJBAF.2012.047358

Ramlee, R., \& Ali, R. U. (2012). Liquidity, initial public offering (IPO) long-term return and government ownership: Evidence from Bursa Malaysia IPO stocks. Asian Academy of Management Journal of Accounting and Finance, $8(1), 39-66$.

Sapian, R. Z. Z., Rahim, R. A., \& Yong, O. (2013). IPO underpricing and aftermarket liquidity: Evidence from Malaysia. International Journal of Business and Society, 14(2), 299-318.

Shleifer, A., \& Vishny, R. W. (1989). Management entrenchment: The case of manager-specific investments. Journal of Financial Economics, 25(1), 123-139. https://doi.org/10.1016/0304-405X(89)90099-8

Subramaniam, R. K., Samuel, S. D., \& Mahenthiran, S. (2016). Liquidity implications of corporate social responsibility disclosures: Malaysian evidence. Journal of International Accounting Research, 15(1), 133-153. https://doi.org/10.2308/jiar-51204

Tayeh, M. I. D. (2010). A comparative analysis of the determinants and pricing of liquidity in floor and electronic trading systems. Doctoral dissertation, Durham University.

Zingales, L. (1995). Insider ownership and the decision to go public. Review of Economic Studies, 62(3), 425-448. https://doi.org/10.2307/2298036

\section{Notes}

Note 1 . To captures stock market liquidity, Amihud's illiquidity measure (ILLIQ) was used. The financial data is available from Thomson Reuters DataStream Database for periods beginning January 1, 2002 to December 2017. Three items facilitate the use Amihud's illiquidity measurement provided in DataStream Data namely stock price, trading volume and stock return. ILLIQ is defined as the daily ratio of absolute stock return to trading volume in Malaysian Ringgit, which is averaged over a certain period.

Note 2. Illiquidity measure of Amihud can be described as the ratio of daily total stock return to volume of trading in Malaysian Ringgit. It means a daily response of the price to one-Ringgit volume of trade. The method of estimating the Amihud's measure is shown in the following equation:

$$
\operatorname{ILLIQ} Q_{\mathrm{iy}}=\frac{1}{\mathrm{D}_{\mathrm{iy}}} \sum_{\mathrm{t}=1^{*}}^{\mathrm{D}_{\mathrm{iy}}}\left|\mathrm{R}_{\mathrm{iyd}}\right| / \mathrm{VOLD}_{\mathrm{iyd}}
$$

